\title{
CYRTANDREAE HAWAIIENSES, SECTIONS SCHIZOCALYCES HILLEBR. AND CHAETOCALYCES HILLEBR.
}

\author{
JOSEPH F. ROCK
}

The present paper is the third of a series dealing with the Hawaiian members of the genus Cyrtandra. The two previous papers were published in this Journal $(4: 604-623 ; 5: 259-277)$.

\section{Section Three: Schizocalyces Hillebr. Fl. Haw. Isl. 325. I 888}

Calyx large, split to near the base into more or less equal broadly ovate to linear-lanceolate lobes. Flowers either single or three rarely more in a corymbose cyme (C. Grayana) or umbel (C. umbracculifora). Leaves linear, lanceolate to obovate-oblong or broadly ovate. Tomentum fulvous or deep ferruginous.

Hillebrand classed under Section Schizocalyces the following species: C. macrocalyx, C. lysiosepala, C. Grayana, C. procera, C. Lessoniana, C. biserrata, $C$. kauaiensis and $C$. Hillebrandi; of $C$. lysiosepala he enumerates three varieties: $\beta, \gamma$ pilosa, and $\delta$; of $C$. Grayana a var. $\beta$ latifolia; of $C$. Lessoniana a variety $\beta, \gamma$ angustifolia, and $\delta$ pachyphylla. Clarke described a new species as $C$. Grayi, which had to be referred to $C$. lysiosepala where it is retained as a variety Grayi in this paper. Hector Léveillé described as new two species $C$. Fauriei and $C$. kamoloensis, which come under the section treated in this paper. The former is identical with Hillebrand's variety $\delta$, of Cyrtandra lysiosepala (Fl. Haw. Isl. 330. I888); it is not specifically distinct and is therefore retained with the name Fauriei as a variety of $C$. lysiosepala; the second species is identical with Cyrtandra Grayana and is consequently reduced to synonymy. Hillebrand's varieties of $C$. Lessoniana have been incorporated with the species because the numerous intermediates do not permit of their being retained as distinct varieties. Hillebrand's var. $\beta$ of $C$. lysiosepala was given the name latifolia. The writer has added four new species, C. halawensis, C. kohalae, $C$. Conradtii, and C. umbracculiflora, which are here described for the first time. The first and third are peculiar to the island of Molokai, the second to the oldest portion of the island of Hawaii, and the fourth to the island of Kauai. To the existing varieties he has added also four new ones: of $C$. lysiosepala a variety haleakalensis from 
East Maui; and of C. Grayana three varieties, var. linearifolia from West Maui, var. lanaiensis from the island of Lanai, and var. nervosa from Mt. Puukukui, also West Maui. The island of Kauai has furnished this section with one of the most distinct species with no immediate or close relatives or varieties of any sort. Molokai has furnished two species: one, C. halawensis, is related to $C$. Grayana but is certainly distinct enough to be classed as a species; $C$. Conradtii belongs in a class with $C$. lysiosepala, but has the appearance of $C$. paludosa or $C$. longifolia, the specific limits here not being as well defined as in the case of the species from Kauai. Hawaii furnishes one species, C. kohalae, which must be classed with the present section, but is in habit similar to the Crotonocalyces. It is the only representative of this section on Hawaii. We see from the distribution of the species of this section that $C$. Grayana has taken possession of the central group of islands, predominating on the western end of Maui where the species and most of its varieties occur. The remaining varieties of C. Grayana are to be found in the immediate neighborhood of West Maui, as for example diagonally across only a few miles distant, on the western end of Molokai (var. Fauriei), and immediately across to the south of West Maui on the island of Lanai, only a few miles distant (var. lanaiensis). Its closest relatives are found also on the western end of Molokai in Halawa Valley (C. halawensis), and on the more distant summit range of Pelekunu-Waikolu in the central part of Molokai (C. procera). Its nearest relatives on Oahu are probably $C$. Oliveri ( $C$. Hillebrandi Oliver) and the specifically more remote $C$. Lessoniana. Most of the species of Cyrtandra found on Hawaii belong to the group of $C$. platyphylla; there are, however, two other species: C. Menziesii, belonging to Section Chaetocalyces, and one other, belonging to Section Microcalyces. Cyrtandra lysiosepala has a distribution similar to that of C. Grayana, being restricted with its varieties to the two central islands, Maui and Molokai. Variety pilosa from Maui seems to bring C. lysiosepala close to $C$. waiolani from Oahu.

\section{Cyrtandra Lessoniana Gaud. Voy. Uranie 447, tab. 54 . 1826}

A shrub r.75-3 m. high, branches terete to subquadrangular, young branches and inflorescence fulvo-silky-tomentose; leaves opposite, ellipticaloblong to obovate-oblong, acute at both ends, minutely denticulate, thin to thick-chartaceous, glabrate or sparsely pubescent above, silky-tomentose underneath with yellowish-brown hair, especially along the midrib, veins, and nerves, $6-21 \mathrm{~cm}$. long, $2-5 \mathrm{~cm}$. wide, on petioles of $\mathbf{I}-3.5 \mathrm{~cm}$.; flowers usually single in the axils of the upper leaves, drooping, rarely two, on a peduncle of $\mathrm{I}-2.5 \mathrm{~cm}$.; pedicels $\mathrm{I}-2 \mathrm{~cm}$.; bracts oblong to linear-lanceolate, 0.6-I cm. long; calyx thin, whitish, glabrate or hirtulose, divided nearly to the base into broadly ovate acute lobes, these angular-valvate in the bud, open and quite reflexed with fruit; corolla exceeding the calyx often by one third, sometimes as long as the calyx, $20-25 \mathrm{~mm}$. long, straight-tubular, ampliate above, with short obtuse lobes, the entire corolla covered with long whitish silky hair, glabrous inside or puberulous; ovary ovoid, glabrous, 
style short, articulate below the deeply lobed, papillate stigma; fruit ovoid, not exceeding the calyx, glabrous.

Ins. Sandwich: Gaudichaud in herb. De Candolle, Paris, Berlin, Delessert, and Gray.

OAHU: Macrae, in herb. Kew, De Candolle, British Museum, Berlin, Vienna; Capt. Beech. Voy. in herb. Kew, Vienna; Nuttall in herb. Kew; British Museum; U. S. Expl. Exped. in Gray Herbarium; Hillebrand no. $33 \mathrm{I}$ in herb. Kew, Berlin; Meyen Reise in herb. Berlin; Kaala Mts., Oahu, Mann and Brigham no. $6 \mathrm{I} 7$ in herb. Cornell University and Gray Herbarium; Wawra on Mt. Waiolani, no. 1692 in herb. Vienna and part in herb. College of Hawaii; Heller on Konahuanui, back of Honolulu, at elevations of 1,500 to 2,000 feet, nos. 2896, 2300a, and 235 I in Gray Herbarium and herb. Cornell University; Rock, Punaluu Mts., Koolau range, dense wet forest, flowering Aug. 8, I908, no. I4, Dec. 7, 1908, nos. I40, I50, 305, Oct. 3I, I9I4, no. I3072, in herb. College of Hawaii; Rock, Kaukonahua Gulch near Wahiawa, May I5, I909, no. 3055 in herb. College of Hawaii; Rock, Waikane Mts., windward side, Jan. 23, I909, no. I 36 in herb. College of Hawaii; Rock, trail to Mt. Konahuanui, Jan. 7, 1909, no.1066 in herb. College of Hawaii; Abbé Faurie, Punaluu Mts. May, igıo (no. 636 Faurie), no. 13072 in herb. College of Hawaii; A. S. Hitchcock, Schofield Barracks, eastern range, July II, I9I6, no. I4024 in U. S. National Herbarium; A. S. Hitchcock, Kalihi Valley, Honolulu, Aug. 2, I9I6, no. I4I08 in U. S. National Herbarium.

Cyrtandra Lessoniana is inclined to be rather variable in size and shape of leaf as well as in size of corolla and calyx and length of peduncle and pedicels. There are a few instances in which an intermediate sțage between C. Lessoniana and C. Pickeringii is exhibited in one or two specimens. To these must be referred the writer's no. 330 from the Koolau range, Punaluu mountains; in this plant the leaves are small and ovate, the calycine lobes are large and similar to those of $C$. Lessoniana but not whitish and thin. The plant is a form of $C$. Lessoniana. The specimens from the Koolau, Punaluu Mountains, have narrower, lanceolate leaves, while Hitchcock's no. 14I08 from Kalihi has the broadest leaves. Hillebrand's var. $\beta$ of this species is evidently only a form of it. Hitchcock's no. I4024 from the Waianae range (Schofield Barracks) would be referable to Hillebrand's var. $\beta$. His varieties angustifolia and pachyphylla cannot well be retained as we have numerous intermediates with leaves ranging from linear-lanceolate to obovate-oblong to ovate leaves, with corresponding variation in the calycine lobes. The species is confined to the island of Oahu. Asa Gray's var. $\beta$ (Proc. Amer. Acad. 5: 352. I861) from West Maui does not belong here, but must be classed with forms of $C$. lysiosepala. 
Cyrtandra lysiosepaida (A. Gray) C. B. Clarke. De Cand. Monogr. Phan. 5: 225. I883-1887

Cyrtandra triflora Gaud. var. $\gamma$ lysiosepala A. Gray, Proc. Amer. Acad. $5: 35$ I. I 86 I.

A shrub 2.5 to $3 \mathrm{~m}$. high; branches obscurely quadrangular, the young parts brownish-pubescent with short hairs; leaves opposite, the upper ones rarely ternate, membranous, elliptical, acuminate at both ends, with serrate margins, pilose above, villose-pubescent below, with yellowish hairs, especially on midrib and veins, $8-14 \mathrm{~cm}$. long, $5-6 \mathrm{~cm}$. wide, on petioles of I 5-40 mm.; inflorescence a three-flowered cyme, the peduncle $3-4 \mathrm{~cm}$.; bracts lanceolate, I cm.; pedicels IO-I $5 \mathrm{~mm}$.; calyx white, parted to the base into spreading, broad-lanceolate to spathulate lobes, $2 \mathrm{~cm}$. long, 3-5 $\mathrm{mm}$. broad; corolla partly villose, the tube erect, the lobes large and spreading; ovary glabrous, style short; stigma broadly lobed; fruit glabrous, shorter than the calyx, ovoid, sessile.

HatvaII: In deep forest, U. S. Explor. Exped.

Maur: West Maui, Kaanapali, Hillebrand (three sheets) in herb. Berlin; East Maui, southern slopes of Haleakala, Hillebrand no. 326 in herb. Kew and Berlin; Honomanu Valley, northeastern slope of Mt. Haleakala, flowering, May I9I I, Rock, in herb. College of Hawaii.

The specimen in Hillebrand's collection in the Berlin Herbarium, from East Maui, bears Clarke's signature and is either the type or co-type of this species; the specimen in Berlin is without number, while the specimen in the Kew Herbarium bears the number 326 . The writer's specimen from Honomanu is identical with the material determined by Clarke, and is the typical C. lysiosepala.

\section{Cyrtandra lysiosepala Fauriei (Lév.) Rock}

Cyrtandra Fauriei Lév. in Fedde Repert. Spec. Nov. Io: 123. I912.

Cyrtandra lysiosepala var. $\delta$ Hillebr. Fl. Haw. Isl. 330. 1888.

Cyrtandra lysiosepala var. molokaiana Rock ms. in herb. Vienna and Berlin.

A shrub with subquadrangular branches; leaves elliptical, acuminate at both ends, thin, coarsely and distantly dentate, $6-12 \mathrm{~cm}$. long, $2-5 \mathrm{~cm}$. wide, hirtellous, dark green above, fawn-colored-pubescent below, on petioles of 2-4 cm.; inflorescence a 3 -flowered cyme; peduncle $2.5^{-6} \mathrm{~cm}$.; bracts ovate, acute; pedicels about $2 \mathrm{~cm}$., the middle one $2.5 \mathrm{~cm}$.; calyx white, the lobes lanceolate, acute, 3-nerved; corolla hirtellous to glabrate; ovary glabrous.

Molokar: Mapulehu, Halawa, and Kalae, Hillebrand in herb. Berlin, sine num.; Mapulehu Valley, flowering March 1910, Rock no. I0338, in herb. College of Hawaii; Pukoo (Mapulehu), fruiting May ı9ıo, Faurie no. 632 , in herb. College of Hawaii (no. I3076).

Plants of this variety were distributed to the herbaria of Vienna and Berlin during the writer's stay in Europe, as Cyrtandra lysiosepala var. molokaiana. It was, however, described by Léveillé as a distinct species 
(C. Fauriei). The plant is a mere variety of $C$. lysiosepala and was as such recognized by Hillebrand, who enumerates it as var. $\delta$. It differs from the species mainly in the ternate leaves, and lanceolate acute sepals instead of spathulate ones; otherwise it is the same.

\section{Cyrtandra lysiosepala latifolia Rock}

Cyrtandra lysiosepala var. $\beta$ Hillebr. Fl. Haw. Isl. 330. I888.

A small tree or shrub, the branches quadrangular, glabrous, but hirtellous at the apices; leaves opposite, broadly ovate, acuminate at both ends, subglabrous above, or with scattered hairs, fawn-colored and pubescent below, dentate to serrulate, $10-15 \mathrm{~cm}$. long, $5-7.5 \mathrm{~cm}$. wide, on petioles of 3-5 cm.; inflorescence a 3-flowered cyme, the peduncle $2.5-3.5 \mathrm{~cm}$., bracts linear-lanceolate, acuminate, pedicels $1.5-3 \mathrm{~cm}$.; calyx lobes subulate (teste Hillebrand) but often linear-lanceolate, acuminate, broadest at the middle, $1.5^{-2} \mathrm{~cm}$. long, $2.5^{-4} \mathrm{~mm}$. wide; corolla the length of the calyx, hirtellous; ovary ovoid, glabrous, the glabrous style articulate near the ovary; fruit ovoid, glabrous.

Maux: East Maui, Hamakua, Hillebrand in herb. Berlin; West Maui, Hillebrand, not in herb. Berlin. Lahaina, in a ravine, elevation $I, 000$ to 2,000 feet, flowering and fruiting Sept. 29, I9I6, A. S. Hitchcock no. I4868, in U. S. National Herbarium.

MolokaI: Pukoo, tree in rain forest, flowering Oct. 8, I9I6, A. S. Hitchcock no. I5O3I, in U. S. National Herbarium.

Var. latifolia comes very close to var. Fauriei and could perhaps be classed with the latter. It differs from it in the opposite, broadly ovate leaves. Hillebrand states that the calycine lobes are subulate, which is not the case with specimens from Lahaina, West Maui. West Maui (Kaanapali and Lahaina) is diagonally across from Mapulehu, Molokai, and separated only by a not very wide channel. Birds can easily fly back and forth between these two nearest points carrying the small seeds in their crops.

Cyrtandra lysiosepala pilosa Hillebr. Fl. Haw. Isl. 33o. i888

A small shrub; branches hirsute at their apices; leaves broadly ovate; thin-membranous, acute at both ends, dentate to serrate but entire towards the. base, Io-12 cm. long, 4-6 cm. broad, hirsute on both faces; petioles 3-4.5 cm.; flowers single on slender peduncles, hirsute, as are the bracts, pedicel, and calyx; calycine lobes about the length of the corolla, subulate; corolla villous in the upper part, but glabrous below, ovary elongate, glabrous; style glabrous; stigmatic lobes short.

Maur: West Maui, Kaanapali, Hillebrand, Aug. I87o, in herb. Berlin; East Maui, Hamakua and Ulupalakua, Hillebrand, coll. Lydgate in herb. Berlin; West Maui, Honokawai gulch along stream, shaded by big rocks, elevation 4000 feet, flowering Aug. 25, 1910, Rock and Hammond no. 8157, in herb. College of Hawaii; East Maui, east of Olinda in wet forest along 
pipe line, elevation 4,000 feet, flowering Oct. I, I916, A. S. Hitchcock no. I4913, in U.S. National Herbarium.

HawaIr: Hilo, Hillebrand, not in herb. Berlin.

A distinct variety and almost of specific value. Comes, however, close to the species save in the subulate calycine lobes. The whole plant is very delicate and membranous. It grows in dense shade along streams on West Maui in company with Gunnera petaloidea, Kadua, Schiedea diffusa, etc. The specimen collected by A.S. Hitchcóck near Olinda has small ovate leaves but agrees otherwise with the type.

\section{Cyrtandra Lysiosepala haleakalensis Rock n. var.}

A shrub with terete branches; leaves opposite, thin chartaceous, elliptical-oblong, acute at both ends, serrulate, Io-I4 cm. long, $3-5.5 \mathrm{~cm}$. wide, dark green above, hispidulous, glabrate to puberulous underneath, greenish, the prominent midrib and secondary nerves brownish and pubescent, on petioles of 3-5 cm.; flowers single, or two on a peduncle of about $1 \mathrm{~cm}$.; bracts linear, green, $7 \mathrm{~mm}$. long, I. $5 \mathrm{~mm}$. wide; pedicels filiform, $\mathrm{I}-\mathrm{I} .5 \mathrm{~cm}$.; calyx greenish-brown tomentose, divided to the base into narrow lineate, almost subulate lobes, the latter I2-20 $\mathrm{mm}$. long, I.5 $\mathrm{mm}$. broad, acute; corolla glabrous or slightly hairy, exceeding the calyx, funnel-shaped, the lobes large and spreading; ovary glabrous, elliptical; style articulate near the base.

MAUr: Ukulele trail to Honomanu, slopes of Mt. Haleakala, flowering Sept., 1910, Rock no. 8564, in herb. College of Hawaii.

A very graceful and delicate variety of Cyrtandra lysiosepala, from which it is mainly distinguished by the thin subglabrate leaves, slender peduncle and pedicels, the narrow linear calycine lobes, and single flowers (rarely two).

\section{Cyrtandra lysiosepala Grayi Rock}

Cyrtandra Grayi C. B. Clarke in DC. Monogr. Phan. 5: 218. I883-1887. Cyrtandra triflora forma typica Wawra (not Gaud.) Flora 30: 563. I872. Cyrtandra lysiosepala Hillebr. (not C. B. Clarke) Fl. Haw. Isl. 330. I888.

Leaves elliptical-oblong, acute at the apex, acuminate at the base, I 5-I $8 \mathrm{~cm}$. long, $5 \mathrm{~cm}$. wide, irregularly dentate to serrate, thin-membranous, hirtellous above, fawn-colored-pubescent below, on petioles of $6 \mathrm{~cm}$.; inforescence a 3-6-flowered cyme; peduncles about $2 \mathrm{~cm}$., the bracts small, $8 \mathrm{~mm}$., linear-lanceolate, the pedicels of varying length, $2.5 \mathrm{~cm}$. with fruit, the lobes linear-lanceolate, acute, white, hirtellous, about I cm.; fruit ellipsoidal, acute, glabrous.

Maui: "Um Waihee," flower buds and fruiting, Wawra no. I820a in herb. Vienna and part in herb. College of Hawaii.

According to Clarke the following specimens have been referred to his C. Grayi by himself: Hillebrand no. 330, in herb. Kew; Seemann, from Oahu, no. 2277, in herb. Kew; Barcley, in herb. British Museum; and Wawra no. I820, in herb. Vienna. 
From the latter specimen (Wawra no. I820a) the College of Hawaii possesses parts, as leaves and inflorescence. The writer has also examined Wawra's plant which bears Clarke's determination; it is obvious that the specimen belongs to $C$. lysiosepala and cannot be retained as a distinct species, but must be considered a variety. It differs from $C$. lysiosepala in the longer leaves and petioles, as well as in the more than 3 -flowered cyme (Clarke states $3^{-12}$-flowered); the sepals are also smaller and acute instead of spathulate.

\section{Cyrtandra Conradtii Rock n. sp.}

A shrub, the branches terete to subquadrangular near the apex, hirtellous; leaves ternate, lanceolate-oblong, $20-26 \mathrm{~cm}$. long, $6.5-8 \mathrm{~cm}$. wide, thin-chartaceous, acute at the apex, gradually merging into a petiole of $2-3.5 \mathrm{~cm}$., hispidulous above, glabrate to minutely pubescent below, but distinctly pubescent along the prominent midrib and veins, the margin sharply serrate; calyx white, divided to near the base into linear, subacute to obtuse lobes, I2-I4 $\mathrm{mm}$. long, 3-4 $\mathrm{mm}$. wide, hirtellous, distinctly nerved; corolla glabrous to puberulous, slightly exceeding the calyx, the tube straight, the lobes oblong; ovary elongate, acute, glabrous as is the style; stigmatic lobes ovate, glabrous.

MoLoKaI: Mapulehu Valley, 300-40o feet elevation, flowering March I9Io, Rock no. I0340 (type), in herb. College of Hawaii.

This species is named for Mr. C. C. Conradt of Mapulehu, Molokai, to whom the writer is indebted for many courtesies and without whose hospitality the exploration of this wonderful valley could not have been accomplished so successfully. Cyrtandra Conradtii is related to C. lysiosepala but has the habit and appearance of $C$. longifolia var. degenerans, or of $C$. paludosa. The calyx is however that of $C$. lysiosepala. The leaves are rather large, ternate, and sharply serrate, and the calycine lobes large and obtuse. Mapulehu Valley and the mountains immediately above it are very rich in Cyrtandreae.

Cyrtandra biserrata Hillebr. Fl. Haw. Isl. 329. 1888

A shrub I.5-2 m. high, the branches and inflorescence hirsute with spreading rust-colored hairs; leaves quaternate, green on both faces, papilloso-hispid on both faces, elliptical-oblong, Io- $12.5 \mathrm{~cm}$. long, $3.75-5 \mathrm{~cm}$. wide, on petioles of $2.5-5 \mathrm{~cm}$., cuspidate, acuminate at the base, deeply and unevenly serrate, almost laciniate; peduncles $8-12 \mathrm{~mm}$. long, 2 -flowered, the pedicels $12-16 \mathrm{~mm}$., the lanceolate bracts $6 \mathrm{~mm}$.; calyx thin, hairy, 8-Io $\mathrm{mm}$. high, parted deeply into five lanceolate, acute lobes; corolla I4-I6 $\mathrm{mm}$. long, villous, exserted, the slender tube slightly curved and ampliate at the throat, the large spreading lobes bilabiate; ovary glabrous, the style $6 \mathrm{~mm}$. long and broadly lobed; berry ovoid, $18 \mathrm{~mm}$.

Molokar: Hillebrand in herb. Berlin and Gray Herbarium, without locality, date or number, part of type in herb. College of Hawaii; Pukoo, Mapulehu, flowering Oct. 8, I9I6, A. S. Hitchcock no. I50I I, in U. S. National Herbarium, part in College of Hawaii Herbarium. 
A very distinct species re-collected only by Prof. A. S. Hitchcock. The leaves are not always biserrate but deeply and irregularly serrate, also sometimes ternate instead of quaternate.

\section{Cyrtandra kauaiensis Wawra Flora 30: 566 . 1872}

A branching shrub, the branches slender, foliose at the apex; leaves membranous, oblong-elliptical, acuminate, subentire, hirsute-pubescent above, the nerves and petiole tomentose with an appressed. ferruginousvelvety tomentum, glabrate between the nerves, $7.5-10 \mathrm{~cm}$. long, more than $2.5 \mathrm{~cm}$. broad; petiole about $2.5 \mathrm{~cm}$. long; peduncle $\mathrm{I}$-flowered, of the length of the petiole, thick, with two caducous filiform bracts above the base; calyx segments foliaceous, green, patent, about $2.5 \mathrm{~cm}$. long, ovate-lanceolate or lanceolate, contracting at the base into short tomentose stipes; corolla exceeding the calyx, the tube partly hirsute, glabrous inside, the lobes ovate, acute, one-third as long as the tube; ovary glabrous, fruit oblong, I.75 cm., apiculate.

KAUAI: "Waelder voin Halemanu," Wawra, type, no. 2058, in herb. Vienna, part of type in herb. College of Hawaii; gulch above Waimea, between the forks of the Waimea river, elevation 2,000 feet, Sept. 30, I895, A. A. Heller no. 2829 , in Gray Herbarium.

This species has been re-collected only once since the time of Wawra, and Hillebrand states "not seen by me." Wawra says "ovary glabrous"; in his specimen the ovary is not glabrous but hirtellous and hirsute towards the apex especially at the base of the style; the calycine lobes are thinmembranous, with undulate margins, prominent midrib, and anastomosing veins, hirtellous on both sides but especially along the nerves.

\section{Cyrtandra procera Hillebr. Fl. Haw. Isl. 329. $\quad$ i 888}

\section{Cyrtandra arborescens Hillebr. in mss.}

Arborescent, $4-6 \mathrm{~m}$. high, the fleshy branches hirsute with dark ferruginous hairs; leaves in whorls of six, linear-oblong or lanceolate, $12.5^{-1} 5 \mathrm{~cm}$. long, $2-5 \mathrm{~cm}$. wide, on petioles of $6.5 \mathrm{~mm}$., acute, sharply and fincly serrulate, truncate at the narrow base, coriaceous, dark green and glabrous above, thickly tomentose underneath; flowers one, two, or three in each axil on a short peduncle of $2-8 \mathrm{~mm}$., the pedicels $16-24 \mathrm{~mm}$.; bracts $6 \mathrm{~mm}$., linear-lanceolate; calyx thickly tomentose or hirsute, I2-18 mm., split to near the base in to five to six linear-lanceolate lobes; corolla I6-18 mm., villous, slightly curved, the large spreading lobes somewhat acute, about 5 $\mathrm{mm}$. long; ovary glabrous.

Molokar: Pali of Pelekunu at a height of 3,000 feet, Hillebrand in herb. Berlin and Gray Herbarium, and part of type in herb. College of Hawaii; near Pelekunu above Kamolo, flowering March I910, Rock no. I034I, in herb. College of Hawaii; at the head of Waikolu Valley, fruiting May 27, 1918, Rock no. 14077, in herb. College of Hawaii.

Cyrtandra procera is recorded by Hillebrand as being arborescent. 
The writer collected this species at the summit ridge of Molokai overlooking the cliffs of Pelekunu Valley. It grows on moss-covered tree trunks and on tree ferns together with Viola robusta, and occasionally grows quite tall and has straight ascending branches. It is related to C. Grayana but differs from it in the single flowers (rarely three), and the peculiar linear truncate leaves which are on petioles of only a few millimeters. With its dark green leaves which are usually convex with the margins rolled downward, and its straight ascending branches, it presents a rather peculiar aspect in the somber rain forest of the heights of Pelekunu. The writer found it also growing at the head of Waikolu Valley at an elevation of 3 ooo feet; there it was a sparingly branching shrub with horizontal and slightly ascending branches. The species is peculiar to the heights of Molokai.

The specimen in the Gray Herbarium, ex coll. Hillebrand, is labeled Cyrtandra arborescens sp. n.; the specimen is 3-flowered immediately below the uppermost leaf whorl.

Cyrtandra Grayana Hillebr. Fl. Haw. Isl. 330. i 888 Cyrtandra kamoloensis Lév. in Repert. Sp. Nov. Fedde Io: I23. I9I2.

A shrub 2.5-3.5 m. high; leaves in whorls of four to six, narrow, spathulate, $25-30 \mathrm{~cm}$. long, including the long petiole merging into them, $3.5 \mathrm{~cm}$. wide near the apex, shortly acuminate, almost entire, thick-chartaceous, papillose above, thickly tomentose beneath with appressed yellow hairs; flowers 8-I2 in an irregular corymbose cyme, the common peduncle $12-24$ $\mathrm{mm}$.; pedicels I8. $\mathrm{mm}$., the broadly lanceolate bracts I2-I4 $\mathrm{mm}$., calyx parted to near the base into five oblong, obtuse lobes, the whole calyx thickly covered with a brown-fulvous tomentum; corolla hairy, with spreading lobes; ovary glabrous; berry broadly ovate, acute, little longer than the calyx.

Maui: Mauna Eeke, 5,000 feet, Hillebrand in herb. Berlin and Gray Herbarium, part of type in herb. College of Hawaii, without date or number; Puukukui, upper forest, flowering, A. S. Hitchcock no. I4748, in U. S. National Herbarium.

MolokaI: Kamolo, June, igı, Faurie no. 646, in herb. Léveillé.

The writer has not collected this species* proper but has collected several varieties of it on West Maui and Molokai. Prof. A. S. Hitchcock of Washington re-collected the typical species on Mt. Puukukui, the highest peak on West Maui. Hillebrand's specimens came from Mauna Eeke, the second highest peak of West Maui. These two mountains are not far apart, but the dense jungle makes it exceedingly difficult to pass from one to the other. Clarke's C. Grayi is not identical with C. Grayana but is intermediate between the latter and $C$. lysiosepala. It differs from the former in the thinner opposite leaves and membranous acute sepals.

* Collected since by the writer on Mt. Eeke, September, rgr 8. 


\section{Cyrtandra Grayana linearifolia Rock n. var.}

A tall shrub of palm-like habit; stems stout, covered with large circular leaf-scars; leaves in whorls of six, linear-lanceolate, $16-20 \mathrm{~cm}$. long including the $2 \mathrm{~cm}$. long petiole gradually merging into them, $1.5 \mathrm{~cm}$. wide, thick, densely brown-tomentose underneath, dark green above, acuminate at both ends; inflorescence on the stem near the ground and on exposed rootlets; flowers arranged in a compound cyme, about $7 \mathrm{~mm}$., bracts ovate-elliptical, acute, these and the whole inflorescence densely brown tomentose; pedicels of very variable length; calyx divided to near the base into linear, acute lobes; corolla tube narrow, ampliate at the throat, the lobes broad and spreading, densely hirsute underneath; ovary linear-oblong, the style short, glabrous; stigmatic lobes broad and thick.

MaUr: West Maui, Honokawai gulch in dense forest, flowering Aug. I9I0, Rock and Hammond no. 820I (type), in herb. College of Hawaii.

The plant here described is almost worthy of specific rank and would perhaps be classed as such by less conservative systematists. The leaves are exceedingly narrow, and the remarkable part is that the flowers are borne at the base of the stem and on exposed rootlets instead of being axillary. No writer on Hawaiian plants had heretofore brought out the facts regarding the location of the inflorescence in some of our Cyrtandreae. There are a number of species in these islands that bear the flowers on exposed roots and along the stem, especially near the ground. Often the writer passed a Cyrtandra which at first glance seemed to be without flower or fruit, which usually occur in the axils of the upper leaves; but on examination they were found to be concealed by foliage and ferns near the ground, often absolutely hidden from sight.

Cyrtandra Grayana latifolia Hillebr. Fl. Haw. Isl. 331. I888

A shrub $3 \mathrm{~m}$. high; leaves quaternate, obovate-oblong, acute to acuminate at both ends, $25-30 \mathrm{~cm}$. long including the petiole, up to $10 \mathrm{~cm}$. wide (teste Hillebr.); petioles of variable length up to $6.5 \mathrm{~cm}$., thick-chartaceous, hirtellous above, densely brown-tomentose beneath, subentire to denticulate; inflorescence a cyme, the flowers less numerous; calyx-lobes ovate to linear, obtuse, tomentose outside, glabrous inside, 3-nerved; corolla hairy; ovary glabrous; style long, the lobes thin and of the width of the style.

Maur: West and East Maui, Hillebrand in herb. Berlin, and part of type in herb. College of Hawaii.

Molokar: Mapulehu Mts. and Valley in dense forest along Wailau Trail, 3,00o feet elevation, flowering March 1910, Rock no. 10335; same locality, May 6, I915, Rock no. 12575, in herb. College of Hawaii.

LanaI: At the head of Mahana Valley, flowering Aug. 2, I910, Rock no. 8128, in herb. College of Hawaii.

Var. latifolia differs from the species in the larger and broader leaves, few $(2-5)$-flowered cyme, and quaternate leaves. It has not been recorded previously from Molokái. The plants from Molokai have a tendency to 
bear the inflorescence along the lower part of the stem as well as in the upper leaf-axils. . The leaves are only $7 \mathrm{~cm}$. in diameter for the most part, but are as much as $10 \mathrm{~cm}$. in width according to Hillebrand. The Lanai specimens must be referred to var. latifolia Hillebr., but they differ slightly from the Maui and Molokai specimens, mainly in the long $(4 \mathrm{~cm}$.) peduncle, 2 -flowered inflorescence, large bracts, calycine lobes, and corolla. It may be termed a form of var. latifolia under the name forma grandis Rock $n$. f.

\section{Cyrtandra Grayana lanaiensis Rock n. var.}

A much branching shrub, the branches tortuous; leaves quaternate, elliptical, 5.5-10 $\mathrm{cm}$. long, IO-24 $\mathrm{mm}$. wide, acute-acuminate at both ends, the margin distantly denticulate to subentire, thick-chartaceous, hirtellous above, with a dense silky-brown tomentum beneath, on petioles of I.5-2 $\mathrm{cm}$.; flowers single or three on a common peduncle of $10-25 \mathrm{~mm}$., in the axils of the upper leaves, the bracts linear, acute; calyx lobes lanceolate, acute to obtuse, brown-tomentose; corolla hirsute; ovary glabrous; fruit elliptical, glabrous.

-LANAI: Summit ridge of Lanai, Haalelepakai, flowering and fruiting July 25, 1910, Rock no. 8036, in herb. College of Hawaii; on largest mountain, flowering Sept. 21, 1916, A. S. Hitchcock no. 14662 , in U. S. National Herbarium.

This variety is a very handsome shrub and differs from the species and other varieties in the small elliptical leaves, short petiole, and short inflorescence, as well as in the smaller flowers.

\section{Cyrtandra Grayana nervosa Rock n. var. .}

A shrub, the branches terete, sulcate when dry; leaves quaternate, elliptical-ovate to obovate-oblong, acuminate at both ends, denticulate excepting the base, thick-chartaceous, hirtellous above, glabrous below with the exception of the very prominently projecting midrib and lateral nerves; inflorescence a short, 3-5-flowered cyme; peduncle I-I.5 cm.; corolla hairy or glabrate, with large lobes, the inflorescence otherwise the same as in var. latifolia: fruits elliptical-oblong, glabrous.

MaUi: West Maui, Puukukui, near the summit in dénse shaded ravines and gulches, the branches covered with moss, flowering and fruiting Aug. 22, I 9I0, Rock no. 8172 (type), in herb. College of Hawaii.

This variety is at once distinguished from the others of the species by its leaves, which are glabrous underneath and expose the reticulated network; the midrib and secondary veins are strongly raised and silky brownpubescent. In the other varieties, as var. latifolia and var. linearifolia, the whole under surface of the leaf is densely matted with a thick, brown, silky tomentum, which does not show the reticulate network. The plant occurs near the summit of west Maui, elevation about 5,000 feet, in the mossy forest; but the inflorescence is axillary instead of near the base of the stem. 
Cyrtandra Oliveri Rock n. name.

Cyrtandra IIillebrandi Oliver in Hillebr. Fl. Haw. Isl. 33I. I888. Not C. Hillebrandii C. B. Clarke.

Leaves opposite, coriaceous with stout ribs and veins, elliptical or ovateoblong, 7.5-I $2 \mathrm{~cm}$. long, 3-5 cm. wide, on petioles of $2.5 \mathrm{~cm}$., acute, denticulate, pubescent above, faintly ferruginous or glabrate beneath; flowers 3-5, cymosely umbellate on a peduncle of $12-24 \mathrm{~mm}$., the pedicels as long or longer, the bracts ovate-lanceolate, Io-I4 $\mathrm{mm}$.; calyx glabrate, thin, 12-1 $8 \mathrm{~mm}$., cleft beyond the middle (deeper on one side), into broad-lanceolate, long-acuminate lobes; corolla little exserted, I8-22 $\mathrm{mm}$. long, pubescent, somewhat curved, with ampliate throat and spreading lobes; ovary glabrous; berry ovoid, elongate, $18 \mathrm{~mm}$. long, enclosed in the calyx.

OAHU: From Nuuanu to Palolo, Hillebrand, in herb. Berlin, and part of type (Nuuanu Valley specimen) in herb. College of Hawaii; Kalihi Valley, flower buds, A. S. Hitchcock no. I4105, in U. S. National Herbarium and part in herb. College of Hawaii.

Cyrtandra Oliveri must be classed with Section Schizocalyces, owing to the thin, deeply lobed calyx. The specific name Hillebrandi must be changed owing to Clarke's $C$. Hillebrandii which antedates that of Oliver in Hillebrand's Flora. That C. Oliveri, C. Pickeringii, C. honolulensis, and $C$. Hillebrandii are closely related there is no doubt. The latter has already been classed as a synonym of $C$. Pickeringii. The writer has a large amount of material at hand but the plants are so variable as to thickness, shape, pilosity of leaf, etc., that it is next to impossible to determine them properly. The species mentioned above are in the same state of evolution as are $C$. platyphylla and its numerous varieties on Hawaii. Certain species of Cyrtandra are exceedingly local while others range over the mountains and valleys in various forms, the extremes of which one would be tempted to describe as new species were not the intermediates available. Unfortunately, the writer has not seen the type of Clarke's C. Hillebrandii, which is in the Kew Herbarium (Hillebrand no. 329). Drake Del Castillo cites it as a synonym of $C$. Pickeringii. Whether he has compared it with other specimens or has determined the synonymy on the strength of the description is doubtful, though the latter is more probable because his synonymy of other species, for example that of $C$. latebrosaC. hareaiiensis-is quite faulty. The description of $C$. Hillebrandii does, however, differ very little from that of $C$. Pickeringii as understood by Hillebrand. The specimen referred by Hillebrand to C. Pickeringii A. Gray has nothing to do with that species, the type of which the writer has only recently been able to examine, but seems to be $C$. Hillebrandii C. B. Clarke. The true Cyrtandra Pickeringii A. Gray has apparently not been re-collected; at least the writer did not find it in any of the collections examined by him either in Europe or America. The type of C. Pickeringii A. Gray consists of a single leaf and an undeveloped inflorescence; the latter 
is hirsute with reddish hairs which stand at right angles to the pedicels. The leaf, which is oblong-lanceolate and acuminate at both ends, has the margin densely covered with reddish hairs as are the midrib and veins; the petiole is not tomentose but almost hirsute. The plants referred by Wawra to $C$. honolulensis seem certainly distinct from $C$. Pickeringii A. Gray and must be retained as a good species instead of as a variety of $C$. Pickeringii. The status of all these species is then as follows:

Cyrtandra Pickeringii A. Gray, type in Gray Herbarium, fragmentary.

Cyrtandra Pickeringii Hillebrand (not A. Gray) apparently corresponds to C. Hillebrandii C. B. Clarke, no. 329 (type) in Kew Herbarium.

Cyrtandra Oliveri Rock, identical with $C$. Hillebrandii Oliver, the latter being a synonym.

Cyrtandra honolulensis Wawra is a good species, and the combination of $C$. Pickeringii honolulensis Rock must be considered a synonym.

It is best merely to give these notes, which may be checked up by future workers or by the one so fortunate as to have the opportunity to examine Clarke's type of $C$. Hillebrandii in the Kew Herbarium.

Oliver's $C$. Hillebrandii ( $=C$. Oliveri Rock) has the calycine lobes divided to the base, while Clarke's $C$. Hillebrandii has the lobes divided to the middle only; as the latter is the only one in Hillebrand's collection with such calycine lobes, it must be taken for granted that it is $C$. Hillebrandii C. B. Clarke. Hillebrand himself identified the particular specimen as C. Pickeringii A. Gray; however, since that identification is erroneous, as can be seen on comparison with the type of $C$. Pickeringii, there remain only two suggestions: that it is either an undescribed species, or it is identical with $C$. Hillebrandii C. B. Clarke. The latter is more probable, and this belief.is strengthened by the fact that Drake Del Castillo refers to C. Hillebrandii C. B. Clarke as a synonym of C. Pickeringii A. Gray.

\section{Cyrtandra kohalae Rock n. sp.}

A small shrub, the stems and branches quadrangular, hirsute in the upper portion with dark ferruginous hairs; leaves oblong to obovateoblong, acuminate at the apex, acute and decurrent at the base, the margins irregularly serrate to denticulate, scatteringly pubescent with whitish, 3-5-celled hairlets which disappear with age, velvety underneath with dark brown tomentum, especially along the midrib and veins, $15-20 \mathrm{~cm}$. long, $5^{-9} \mathrm{~cm}$. wide, on petioles of $3 \cdot 5^{-5} \mathrm{~cm}$.; inflorescence in the upper axils of the leaves; peduncle $1.5^{-2.5} \mathrm{~cm}$. long, bearing either one single flower and without a pedicel or bearing six flowers on pedicels of variable length, brownish-hirsute as are the pedicels; bracts linear-lanceolate, about 2.5 $\mathrm{cm}$. in length; pedicels 5-30 mm.; calyx tube exceedingly short, barely 4 $\mathrm{mm}$.; the lobes filiform to subulate or linear, and long-acuminate, about 2 $\mathrm{cm}$. in length, $\mathrm{I}-2 \mathrm{~mm}$. broad; corolla small, about $12 \mathrm{~mm}$. long, tubular and slightly curved, glabrous to hirtulose outside as are the reflected lobes; ovary glabrous as is the articulate style; fruit subglobose to ovate, not exceeding the calycine lobes. 
HAwAII: Woods of Kohala, rain forests at an elevation of 4,000 feet; flowering and fruiting June 10-16, I910, Rock no. 836 (type), in herb. College of Hawaii (Plate III).

This new species is very near C. Menziesii Gray, but differs from it in the coriaceous, velvety-tomentose leaves, the robust habit, and much larger calycine lobes.

Cyrtandra kohalae is apparently related to $C$. platyphylia, from which it differs, however, in the oblong, long-acuminate leaves, but especially in the subulate-linear calycine lobes and small flowers. It is at a glance distinguishable from $C$. platyphylla by the spreading, 2-cm.-long calycine lobes; the tube of the calyx is exceedingly short. This species seems to link together the sections Crotonocalyces and Schizocalyces. The appearance of leaf as well as habit of plant would place this species in the former section were it not for the distinct calyx.

\section{Cyrtandra halawensis Rock n. sp.}

A tall shrub, $3 \mathrm{~m}$. or more high; leaves opposite, elliptical to ovateoblong, acute at both ends, $13-30 \mathrm{~cm}$. long, 7-14 cm. broad, thin-membranous to chartaceous, hispidulous above, silky-brown tomentose beneath, the margins serrate-dentate excepting the slightly uneven-sided base, this merging into a petiole of $2.5^{-1}$ I $\mathrm{cm}$.; inflorescence axillary, a 3 -flowered cyme, yellowish-brown tomentose throughout, the common peduncle I.5-2.5 cm. long; bracts linear-lanceolate, acute, $5^{-12} \mathrm{~mm}$; ; pedicels of variable length in the same cyme, 4-20 $\mathrm{mm}$. long; calyx lobes linear, $2 \mathrm{~cm}$. long, $2-3 \mathrm{~mm}$. wide, long-acuminate; corolla as long as the calycine lobes or less, of even width, curved and hairy in the upper third; ovary conicaloblong, glabrous, the style articulate below the middle, stigmatic lobes oblong; fruit ovate-oblong, acute, I 5 by Io $\mathrm{mm}$., glabrous.

MolokaI: Forests of Halawa Valley on the plateau above the falls, along stream bed and the outskirts of forest, flowering and fruiting April I9Io, Rock no. 70Io (type), in herb. College of Hawaii (Plate IV).

Cyrtandra halawensis, while not so distinct a species as C. umbracculiflora, is sufficiently distinct to be classed as a species. It is true that it comes close to C. Grayana var. latifolia Hillebr., but differs from it in the very large, long, linear calycine lobes; the leaf margins are serrate-dentate, while those of C. Grayana are subentire.

\section{Cyrtandra macrocalyx Hillebr. Fl. Haw. Isl. 329. I 888}

Cyrtandra macrostegia Hillebr. mss. (in Gray Herbarium).

Arborescent, 4-5 m. high, the branches moderately hirsute; leaves in whorls of four, elliptical-oblong, acuminate at both ends, serrulate, Io-12.5 $\mathrm{cm}$. long, $3.75-4.5 \mathrm{~cm}$. wide, on petioles of about $\mathrm{I} 2-18 \mathrm{~mm}$., thick-chartaceous, with prominent veins, sparingly hairy above, with a faint ferruginous tomentum beneath; peduncle $8-16 \mathrm{~mm}$., bearing one or two flowers on pedicels of 12 to $14 \mathrm{~mm}$., the bracts large, foliaceous, ovate, $12-24 \mathrm{~mm}$. long, 
8-I2 mm. wide; calyx of thick texture, pubescent, large, crateriform, I8-24 $\mathrm{mm}$. long, divided to the middle into large foliaceous ovate-obtuse lobes of 8-10 $\mathrm{mm}$, in width; corolla little exserted, slightly curved, pubescent.

Molokas: Pali of Wailau and Pelekunu, July ı 870, Hillebrand in herb. Berlin and Gray Herbarium; at the foot of a waterfall near Kamoku, flowering March I910, Rock. no.6i i 8, in herb. College of Hawaii.

The single sheet of this species in the Berlin Herbarium bears the following legend:- "Cyrtandra Pickeringii? A. Gray." The specific name Pickeringii was crossed out by Hillebrand and the name macrostegia was substituted for it. He also states: "calyx corolla incurva paulla breviore, bracteis late foliaceis-trunco arboreo. July i870."

Cyrtandra macrocalyx is a distinct species, but Hillebrand's description of it is not quite correct, or rather the dimensions of leaf, petiole, peduncle, and pedicels are not the maximum dimensions actually occurring. The following dimensions may be supplied from a large series of specimens of this species: leaves up to I $5 \mathrm{~cm}$. long, serrulate to coarsely serrate, petioles up to $3.5 \mathrm{~cm}$., peduncles up to $2.5 \mathrm{~cm}$., pedicels up to $34 \mathrm{~mm}$.; the texture of the calyx is thin rather than thick. The species is the common form on Molokai, where it grows on the exposed open ridges as well as in shaded ravines along stream beds. Those found in open places have the leaves more rounded and covered with a fulvous tomentum than those found in shady places; those of the latter locality have the leaves long and acuminate, of a fleshy texture, and of a greener color; the flowers are also larger.

\section{Cyrtandra umbracculiflora Rock n. sp.}

A stout shrub $3 \mathrm{~m}$. high, the stems stout, with thick nodes, pubescent throughout; leaves (opposite?) alternate, large, ovate, acute at the apex, uneven-sided at the base, each side with a distinct sinus, the petiole apparently branching at the apex and forming a sinus on each side, $25 \mathrm{~cm}$. long, is cm. wide, thick-chartaceous, the margin irregularly crenate to sinuately notched, the lobes with callous teeth at irregular intervals, hirtellous above, tomentose beneath with yellowish-gray hairs, especially along the stout midrib and veins; petiole clasping, stout, Io-I $5 \mathrm{~cm}$. long, densely yellowish-tomentose; inflorescence yellowish-tomentose throughout, subumbellate, opposite to alternate, arranged along the stem, the common peduncle stout, flattened, $4.5 \mathrm{~cm}$. long, $4 \mathrm{~mm}$. broad, thickening and expanding subflabellately into two short thickened rays $5 \mathrm{~mm}$. in length, each dividing again, pedicels of about even length, I3-I 5 in number, $3 \mathrm{~cm}$. long; bracts subfoliaceous, lanceolate, acute to acuminate, $2.5 \mathrm{~cm}$. long, I cm. broad; calyx irregularly lobed to near the base into broad, ovate-lanceolate segments acute at the apex, contracted below, indistinctly nerved, I2-I5 $\mathrm{mm}$. long, 5-7 mm. wide, hirtellous to tomentose inside and outside, corolla unknown; fruit ovate-oblong, rounded at the apex, crowned by two-thirds of the style, the latter articulate in the last (upper) third; stigmatic lobes broadly ovate, with the margins reflexed.

KAUAI: Forests of Kaholuamano along Waiakealoha stream, also Waialae 
Valley along stream bed, 3,500 feet elevation, in company with Cyrtandra Wawrai fruiting Sept. 1909, Rock no. 596I (type), in herb. College of Hawaii (Plate V).

Cyrtandra umbracculiflora is one of the most distinct new species of Cyrtandra found in the Hawaiian Archipelago. It is remarkable for its umbellate inflorescence and peculiar leaf bases. As already remarked, Kauai possesses the most distinct species of Cyrtandreae as well as of Lobelioideae. The same can be said of nearly all the other native plants of that island. It is somewhat difficult to place this species, as it is eligible for both sections Crotonocalyces and Schizocalyces. The writer has decided to place it in the latter section on account of the deep division of the calyx, notwithstanding the very broad lobes which in one or two instances seem to be united on one side, thus forming a very broad lobe with three short triangular teeth. The large leaves would also place it with Section Crotonocalyces. In habit it resembles $C$. Wawrai, but is otherwise quite different.

\section{Section Four. Chaetocalyces Hillebr. Fl. Haw. Isl. 326. 1888}

Calyx deeply split into linear or subulate lobes. Flowers mostly subumbellately arranged. Leaves thin, glabrous or hispid, large, ovate to oblong, decurrent at the base or acute at both ends.

The section Chaetocalyces, which Hillebrand still further designates as "virides," comprises the following species: Cyrtandra Menziesii, C. kalichii, C. waiolani, C. gracilis, C. Macraei, and C. Lydgatei. The following varieties may be recorded: C. kalichii var. tristis, C. Macraei var. parvula, C. gracilis var. subumbellata, and doubtfully C. Menziesii var. Gaudichaudiana. While the other sections furnished a number of new species and still more varieties, this section furnished only one new variety. It would appear that these species are more settled than are those of other sections occurring on the more centrally located islands of the group; of the species described in this section four occur on the island of Oahu, only one on Molokai and West Maui, and one on Hawaii. Section Microcalyces is closely connected with Section Chaetocalyces, and the majority of the species of the former occur also on Oahu.

C. tristis Hillebr. ms., which was described by Clarke, has been reduced to a variety of $C$. kalichii Wawra. Hillebrand united it with the latter and quoted his manuscript name as a synonym but not as a species. Clarke even placed it in a separate section. It took careful study to distinguish the two plants from dried material. None of the species belonging to this section have as yet been found on Kauai, the oldest island of the group.

Cyrtandra Menziesir Hook. \& Arn. Bot. Beechey Voy. 9I. I84I Cyrtandra Brighami C. B. Clarke in DC. Monogr. Phan. 5:22 I. I883-I887

Branches obscurely quadrangular, the young shoots densely ferruginouspilose at the apex; leaves quaternate, oblong, acuminate at both ends, 
subdenticulate to serrate, $9 \mathrm{~cm}$. long, $3 \mathrm{~cm}$. broad, scaberulous above, yellowish-pubescent beneath or almost glabrate; petiole $3 \mathrm{~cm}$. long; peduncle IO-I5 mm. long; pedicels six to fifteen, umbellately arranged, IO-I5 $\mathrm{mm}$. long; calycine lobes linear or subulate, somewhat villous; corolla straight, pubescent; fruit ovoid, glabrous.

Insulis Sandwich: Menzies in the Kew Herbarium, Menzies et Nelson in herb. British Museum. Gaudichaud no. 85I Voyage Bonite, in herb. Berlin and Gray Herbarium, and herb. College of Hawaii.

HawaII: Woods of Kona, Hillebrand in herb. Berlin, and herb. College of Hawaii; Mann and Brigham no. 3Io, in Gray Herbarium and herb. Cornell University (Plate VI).

The writer is familiar with this species only from herbarium specimens. His own species $C$. kohalae comes very close to it. Clarke's $C$. Brighami cannot very well be separated from $C$. Menziesii Hook. \& Arn. There are only very slight differences such as texture of leaves, slightly shorter peduncles, etc. The main features are exactly the same. Clarke states that it differs from C. Menziesii Hook. \& Arn. primarily in the larger fruits which even in a young state do not resemble those of C. Menziesii. Hawaiian plants are extremely variable, and different-sized fruits may be found on a single Cyrtandra bush. Clarke very briefly describes or rather mentions a var. $\beta$ Gaudichaudiana "with leaves always opposite and never whorled, mature fruit $8 \mathrm{~mm}$. long, ellipsoidal, not exceeding the calyx." It was collected by Gaudichaud and specimens are to be found in the herbaria of De Candolle and Delessert; according to Clarke it was found together with C. paludosa and was perhaps confused with it by Gaudichaud. Hillebrand reports: "My specimens exhibit both opposite, ternate, and quaternate leaves, while in those collected by Menzies, Gaudichaud, and Mann they were quaternate." The variety $\beta$ Gaudichaudiana of Clarke may be identical with Hillebrand's specimens with opposite leaves.

Gaudichaud's no. 85I, Voyage Bonite, of which specimens may be found in the Berlin and Gray herbaria, is referred by Clarke to. C. Brighami. The Gaudichaud specimen in the Gray Herbarium was identified by Asa Gray as C. Menziesii and marked as such in his own handwriting.

Mann and Brigham's no. 310, which served as the type of C. Brighami C. B. Clarke, and of which a specimen is in the Gray Herbarium, was also identified by Asa Gray as C. Menziesii. The type is in the Kew Herbarium.

\section{Cyrtandra kalichil Wawra Flora 30:564. 1872}

A shrub $2 \mathrm{~m}$. high, simple, erect; leaves broadly ovate, membranous, acute at the apex, rounded at the base, decurrent to half the length of the petiole, rough hispid above, ferruginous-pubescent beneath, $3 \mathrm{dm}$. long, I $8 \mathrm{~cm}$. wide, coarsely dentate, the teeth again serrulate; petioles about Io $\mathrm{cm}$., naked, not winged in the lower $5^{-6} \mathrm{~cm}$., winged or the leaf decurrent along the upper $4-5 \mathrm{~cm}$. of petiole; peduncle axillary, this and the pedicels, bracts, and calyx hirsute with yellowish hairs; peduncles $12 \mathrm{~mm} ., 3^{-5}$ 
flowered; bracts about $6 \mathrm{~mm}$., acute; pedicels I0-1 $2 \mathrm{~mm}$., the lateral ones shorter; calyx 7-Io mm., including the linear lobes, the latter more or less spreading; corolla hirsute outside toward the apex; the tube slender, exserted, nearly twice as long as the calyx, ampliate at the throat; ovary glabrous but hirtellous at the base of the style, the latter reddish-hirsute.

OAHU: "Felsschluchten des Kalichithals," Wawra no. 1788 in herb. Vienna, clastotype in herb. College of Hawaii; Hillebrand, in herb. Berlin (included with $C$. tristis); Punaluu Mts., Koolau range elevation 2000 feet, flowering Nov. I4-2I, I908, Rock no. 93I; same locality Dec. 3-I4, I908, no. 152, and Oct. 3I, I914, no. 1759, in herb. College of Hawaii; Wahiawa, Kaukonahua gulch, flowering May I5, 1909, Rock and Hosmer no. 3028, in herb. College of Hawaii.

Clarke was certainly a keen systematist; he correctly separated Cyrtandra kalichii Wawra occurring in the western range from plants growing at much lower elevations in the eastern range, for which plants he adopted Hillebrand's manuscript name $C$. tristis. Hillebrand classed both of these plants together and records his $C$. tristis as a synonym of $C$. kalichii. There are certainly decided differences between these plants; the most striking is in the petiole, which in C. kalichii is winged, or the leaf is decurrent about to the middle of the petiole, which is then naked. In C. tristis the petiole is much stouter and shorter and is broadly winged to the clasping base. The corolla tube is nearly twice the length of the calyx and is narrow and slender and also exserted; in C. tristis the corolla tube is not exserted; in fact the whole corolla is almost included, only the spreading lobes being free. In $C$. kalichii the calycine lobes are spreading, while in $C$. tristis the calyx is cylindrical, with the lobes erect. The leaves of $C$. kalichii are ovate to suborbicular, the margins are coarsely dentate and the teeth again serrulate; in $C$. tristis the leaves are obovate to ovate-oblong, and the margin is denticulate only. However, the plants are very closely related, and it is perhaps better to report Clarke's C. tristis as a variety of $C$. kalichii Wawra. Hillebrand writes C. Kalihii instead of Kalichii as Wawra spells it; the former spelling is correct. Wawra identified the aspirated Hawaiian $h$ with the German $c h$, hence his improper spelling.

\section{Cyrtandra kalichit tristis (Hillebr.) Rock n. name}

Cyrtandra tristis Hillebr. ms. in C. B. Clarke, DC. Monogr. Phan. 5: 227. I $883-\mathbf{r} 887$.

Cyrtandra Kalihii Hillebr. (not Wawrà) Fl. Haw. Isl. 334. I 888 (in part).

A sparingly branching shrub, the stems fleshy, stout, subterete; leaves large, ovate-oblong, denticulate, up to $45 \mathrm{~cm}$. long and $20 \mathrm{~cm}$. broad including the short winged fleshy clasping petiole; cymes many-flowered; peduncles about $6 \mathrm{~mm}$., these and the whole inflorescence hirsute with dark reddishbrown hairs; pedicels of variable length; calyx cylindrical, the linear lobes erect and as long as the corolla; ovary glabrous; style puberulous, stigma of two elongate lamellae. 
OAHU: In deep, gloomy ravines, Hillebrand in herb. Berlin and Gray Herbarium, and Kew; Mt. Kaala, Hillebrand, in herb. Berlin and College of Hawaii; Mt. Olympus trail, dense shade, flowering Sept. I917, Rock, in herb. College of Hawaii; deep ravines of Palolo Valley along stream beds and waterfalls, flowering February 9, I9I8, Rock and Crawford no. I308I, in herb. College of Hawaii.

The plant in question is certainly distinct enough at least to be classed as a variety of $C$. kalichii. Clarke described it as a species and even classed it in a different section from $C$. kalichii. For further consideration of the specific or varietal merit of this plant see the discussion under C. kalichii.

\section{Cyrtandra Waiolani Wawra Flora 30:566. I 872}

Cyrtandra hirsuta Hillebr. ms. not Jack.

?Cyrtandra Hillebrandi Vatke ms. not Oliver ms.

Cyrtandra lasiodon C. B. Clarke ms.

Cyrtandra oahuensis Lév. in Fedde Repert. Sp. Nov. ro: 124. 1912

A small tree with slender branches; leaves elliptical, acuminate at both ends, thin herbaceous, hirsute above with multicellular hairs, sparingly pubescent beneath but strongly hirsute on ribs and veins, $7-12 \mathrm{~cm}$. long, $2.5-4.5 \mathrm{~cm}$. wide, on petioles of $1.5^{-2.5} \mathrm{~cm}$.; peduncles one-flowered of the length of the petiole, or 2 -flowered and the pedicels half the length of the peduncle; bracts linear, I cm.; calyx campanulate, $1.5 \mathrm{~cm}$., deeply split into linear, hirsute lobes which are recurved at the apex when with fruit; corolla glabrous at base, hirsute at the constricted throat and below the lobes, glabrous within; ovary glabrous; style hairy, articulate at the base, deeply bilamellate; fruit large, ovoid-ellipsoidal, apiculate.

OAHU: "Waldschluchten des Waiolani," Wawra no. I792, in herb. Vienna, and part of type in herb. College of Hawaii; gulches of Konahuanui, Kalihi, Moanalua, Kaala, Hillebrand, in herb. Berlin, herb. College of Hawaii, and Gray Herbarium; Punaluu Mts., Koolau range, flowering Aug. I908, Rock, in herb. College of Hawaii; same locality, Nov. I4-2 I, 1908, Rock no. 884, in herb. College of Hawaii; Punaluu, May I9ro, Faurie (as C. oahuensis), co-type in herb. College of Hawaii.

The species is by no means confined to $\mathrm{Mt}$. Waiolani, but occurs all along the western range of the Koolau mountain chain. The specimens from the Punaluu mountains are a little less hairy and occasionally the calycine lobes are a little wider, which fact perhaps persuaded Léveillé to describe it as a new species.

Cyrtandra Gracilis Hillebr.; C. B. Clarke, Monogr. Phan. 5:226. I883I 887 ; Hillebr. Fl. Haw. Isl. 333. I 888

A shrub 2.5-3.5 $\mathrm{m}$. high, the angular branches slender, faintly pruinose, those and the cyme soon glabrate, leaves opposite, membranous, green on both faces, paler beneath, puberulous along the veins or thinly pubescent 
over the whole lower surface, glabrous above, ovate or elliptical-oblong, Io-20 cm. long, 5-10 cm. wide, on petioles of $2.5-8 \mathrm{~cm}$., caudately acuminate at the apex, serrulate, suddenly contracting and shortly decurrent; flowers generally three or five to seven, on a common peduncle of about $15 \mathrm{~mm}$.; pedicels slender, $2-5 \mathrm{~cm}$., thickening above; bracts linear-lanceolate, 6-12 $\mathrm{mm}$.; calyx glabrate, split to the base into linear lobes $12-18 \mathrm{~mm}$. in length, shorter than, or equaling, the corolla; corolla pruinose, slightly curved or suberect, $25 \mathrm{~mm}$. long, ampliate at the throat; ovary glabrous, elliptical, the style hirtellous, slender; stigmatic lobes obovate, spreading; mature fruit $22 \mathrm{~mm}$. long, $5 \mathrm{~mm}$. broad, narrow-oblong, acute, sessile.

OAHU: near Palolo (on both mountain ranges), not uncommon in Nuuanu; Konahuanui gulch, Hillebrand, in herb. Kew and Berlin and Gray Herbarium, co-type in herb. College of Hawaii; Punaluu Mts., Koolau range, along stream beds, flowering Dec. 3-14, 1908, Rock nos. 325, 742 I, 762 , in herb. College of Hawaii (Plate VII).

Cyrtandra gracilis is somewhat variable; the specimens from the Punaluu mountains have a stout quadrangular stem and not a slender one, and the leaves are larger and have a close fenestrate venation; the petioles are also stouter, and the peduncles are shorter. Hillebrand states "flowers generally three"; his"specimens have nearly all from six to seven flowers; the calycine lobes which, he remarks, are generally longer than the corolla, are usually only one half the length of it. His variety subumbellata seems to be only a large form of the species, but owing to its extraordinary size is here retained as a variety.

The specimen in the Gray Herbarium has the leaves more ellipticaloblong and the exceedingly long pedicels measuring over $5 \mathrm{~cm}$., while the peduncles vary from $I$ to $2 \mathrm{~cm}$.

The long slender calycine lobes exceed the fruit, but do not quite equal the flowers in length.

Cyrtandra gracilis subumbellata Hillebr. Fl. Haw. Isl. 334. i888

Habit of the species; branches stout quadrangular, with stout nodes at the places of leaf attachment; leaves large, broadly ovate, caudately acuminate at the apex, decurrent at the base for a short distance, $22-3 \mathrm{I} \mathrm{cm}$. long, Io-18 cm. wide, thin membranous, chartaceous, dark green above, grayishpuberulous underneath, with prominent nerves; margins broadly dentate excepting the base; petiole $3.5^{-7} \mathrm{~cm}$. long; inflorescence axillary, extending down the stem; the common peduncle $1.5 \mathrm{~cm}$.; flowers six to eight on slender pedicels of $12-25 \mathrm{~mm}$.; bracts numerous, linear, up to $17 \mathrm{~mm}$. long; calyx as in the species, the lobes linear, as long as the corolla or shorter; corolla, smaller, 16-20 mm. long, pruinose.

OAHU: Hillebrand; in dense forest along Kaliuwaa stream in the mountains above Punaluu, above second waterfall, flowering Dec. 24-28, 1908, Rock no. 416, in herb. College of Hawaii; same locality, Oct. 3I, 1914, Rock no. 13078 , in herb. College of Hawaii.

There is no specimen extant in the Berlin Herbarium of Hillebrand's 
collection. There is no doubt that the writer's plant is identical with the description. It is larger in every way than the species, the leaves are certainly the size of $C$. Macraei and even larger, but the calycine lobes are long and linear to almost subulate. It is an intermediate between $\mathrm{C}$. Macraei and $C$. gracilis, or $C$. gracilis is a variable species with larger leaves in shaded situations and smaller ones in open or exposed forest ridges.

\section{Cyrtandra Macraei A. Gray. Proc. Amer. Acad. 5: 352. 1862}

A shrub about $3 \mathrm{~m}$. high or more, the branches strictly quadrangular, subherbaceous, green, with a pruinose efflorescence towards the apex; leaves broadly ovate, opposite, I5-22 cm. long, ro-I $5 \mathrm{~cm}$. wide, acuminate at the apex, rounded or slightly decurrent at the base, thin-membranous, glabrate above, canescent underneath with a faint pubescence, the margin dentate to the base; petiole stout, pruinose, 5-I4 cm. long; inflorescence a subumbellate, pruinose cyme, axillary in the upper leaves and extending some distance down the stem, in the fleshy ascending branches axillary in the lowest leaves; flowers numerous, ten to twenty, on a common peduncle of 5-6 mm., the latter branching into, or bearing at its apex, three rays, each bearing a number of slender pedicels of variable length, those with fertile flowers reaching a length of $8 \mathrm{~mm}$.; calyx parted to near the base into acute or acuminate, lanceolate lobes $2-3 \mathrm{~mm}$. in length; corolla tube of even width, slender, curved, $12 \mathrm{~mm}$. long, $3 \mathrm{~mm}$. wide, with small pruinose lobes; ovary pruinose, elliptical; style articulate at or below the middle; fruit oblong, rounded at both ends, $12 \mathrm{~mm}$. long, $7 \mathrm{~mm}$. wide when fully mature.

OAHU: Macrae, May I825 (type), in Gray Herbarium; Gaudichaud, Voyage Bonite; Brackenridge, U. S. Explor. Exped. (teste Gray); eastern division of main range, Niu to Wailupe Valley, Hillebrand no. 325 , in herb. Kew and Berlin, part of specimen (ex Wailupe V.) in herb. College of Hawaii; Mann and Brigham, without number, in herb. Cornell University; small ravine of Palolo Valley along stream bed, flowering February 9, r9I8, Rock no. I3077, in herb. College of Hawaii (Plate VIII).

Cyrtandra Macraei is exceedingly close to $C$. gracilis, but differs from it in the short calycine lobes, shorter corolla, and numerous flowers.

\section{Cyrtandra Macraei parvula Rock n. var.}

A small tree or shrub $3 \mathrm{~m}$. high, with numerous slender, angular branches, pruinose towards the apex; leaves ovate-oblong, caudately acuminate at the apex, cuneate at the base, bright green and puberulous along the nerves and leaf-base above, grayish to canescent below, and pubescent, especially along the midrib and nerves, thin-chartaceous, denticulate excepting the base, Io-I $5 \mathrm{~cm}$. long, $5.5-8 \mathrm{~cm}$. wide, on petioles of $3.5-6.5 \mathrm{~cm}$.; inflorescence densely crowded in the axils of the upper leaves, pruinose, the peduncle 3-4 mm.; pedicels $5 \mathrm{~mm}$.; flowers numerous, glomerate; calyx $3 \mathrm{~mm}$., including the lanceolate lobes; corolla $8 \mathrm{~mm}$., white-pruinose in the bud, little less so when mature, berry elliptical, acute, 6-8 $\mathrm{mm}$. long.

OAHU: In deep ravines of Palolo Valley, along water-courses, flowering 
and fruiting February 9, I9I8, Rock no. I3079 (type), in herb. College of Hawaii.

This variety differs considerably from the species; mainly in the smaller leaves and dense agglomerate inflorescence which is confined to the upper leaf axils; the flowers are much smaller, as are the fruits.

Cyrtandra Lydgatei Hillebr. Fl. Haw. Isl. 335. 1888

A small tree 4-6.5 m. high, branches villous with pale ochraceous hairs; leaves opposite, thin, flaccid, green on both sides, sparingly hispid with multicellular hairs above, puberulous along rib and nerves beneath, pubescent towards the base, broadly ovate or suborbicular, Io to $22 \mathrm{~cm}$. long, 6-14 $\mathrm{cm}$. wide, shortly acuminate at the apex, rounded or cuneate-decurrent, somewhat uneven-sided, at the base; petiole not margined, $3-10 \mathrm{~cm}$. long; flowers two to seven, subumbellately arranged on a peduncle of 1.5 $\mathrm{cm}$., the pedicels I-I. $5 \mathrm{~cm}$.; bracts narrow-lanceolate, thin, $6-8 \mathrm{~mm}$.; calyx green, hirsute, cylindrical, divided to near the base into linear-acute to spathulate lobes; corolla slightly. exserted, hirsute, 12-r4 mm., the tube narrow, curved, the lobes large, spreading; ovary glabrous, with broadly lamellate style; fruit broad, ovoid, I5 $\mathrm{mm}$. long.

MolokaI: In deep ravines of Kalae and Mapulehu, Lydgate, in herb. Berlin and Gray Herbarium; Mapulehu Valley, fruiting April I9Io, Rock, in herb. College of Hawaii; Halawa Valley, fruiting April I9ro, Rock, in herb. College of Hawaii; Kalae, in deep gulches, flowering May 1918, Rock and Dunbar no. 14064, in herb. College of Hawaii.

MAUI: Gulch of Honokawai, Kaanapali, West Maui, Aug. I87o, Hillebrand, in herb. Berlin and Gray Herbarium, and part of type in herb. College of Hawaii; Honomanu gulch, northeastern slope of Haleakala, East Maui, flowering May I9I I, Rock, in herb. College of Hawaii.

The specimens from Maui, especially East Maui, have the calyx lobes decidedly spathulate, while those from Molokai have the calycine lobes linear-lanceolate, acute. The leaves are somewhat larger than the dimen- . sions given by Hillebrand. A distinct species which comes close to $C$. lysiosepala, save that the calyx lobes are not reflexed and the calyx remains cylindrical in shape, the leaves are very much larger, and the inflorescence is up to 7 -flowered, subumbellate.

College of Hawail, Honolulu. 


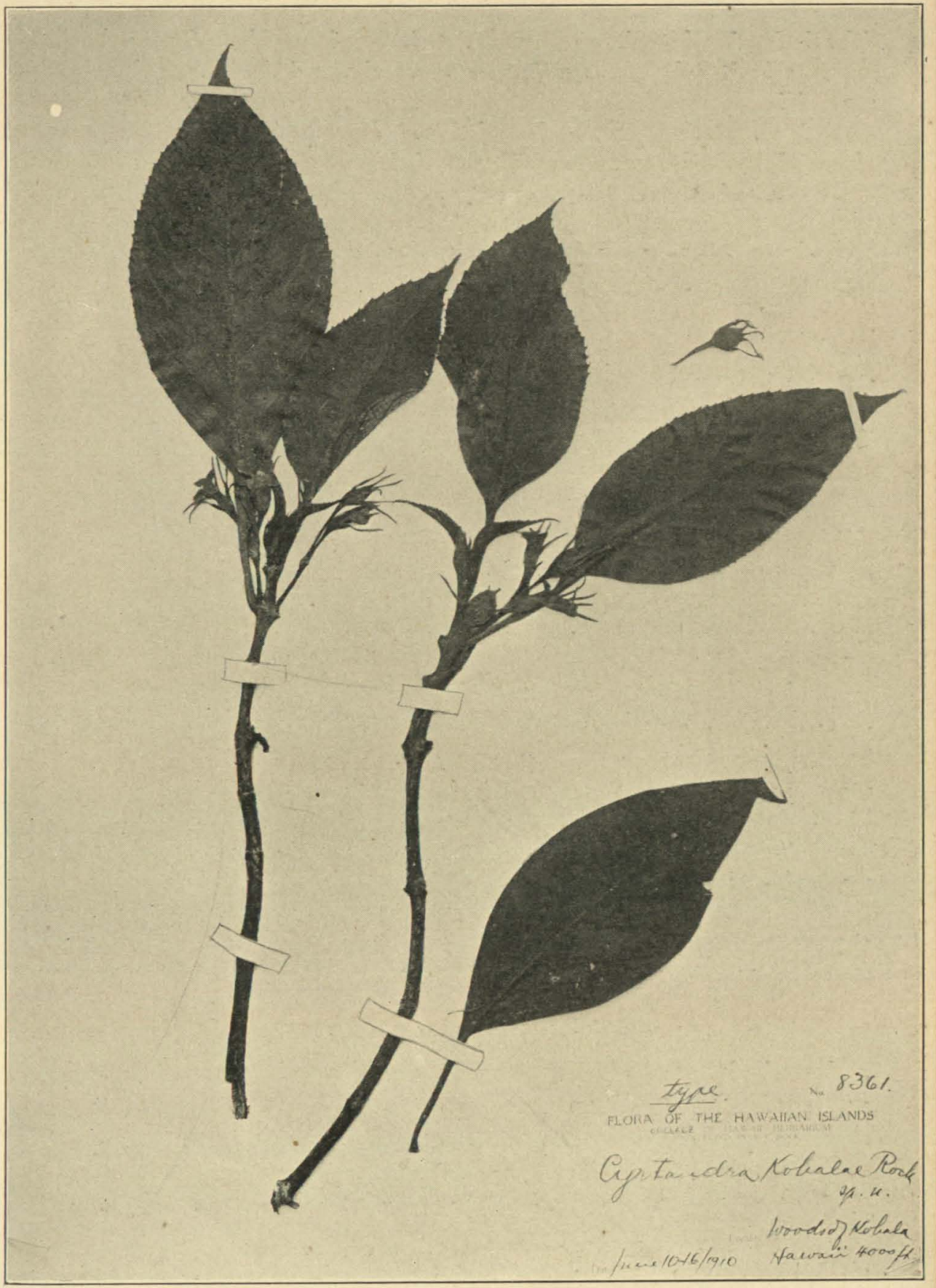

Rock: Type of Cyrtandra kohalae Rock. 


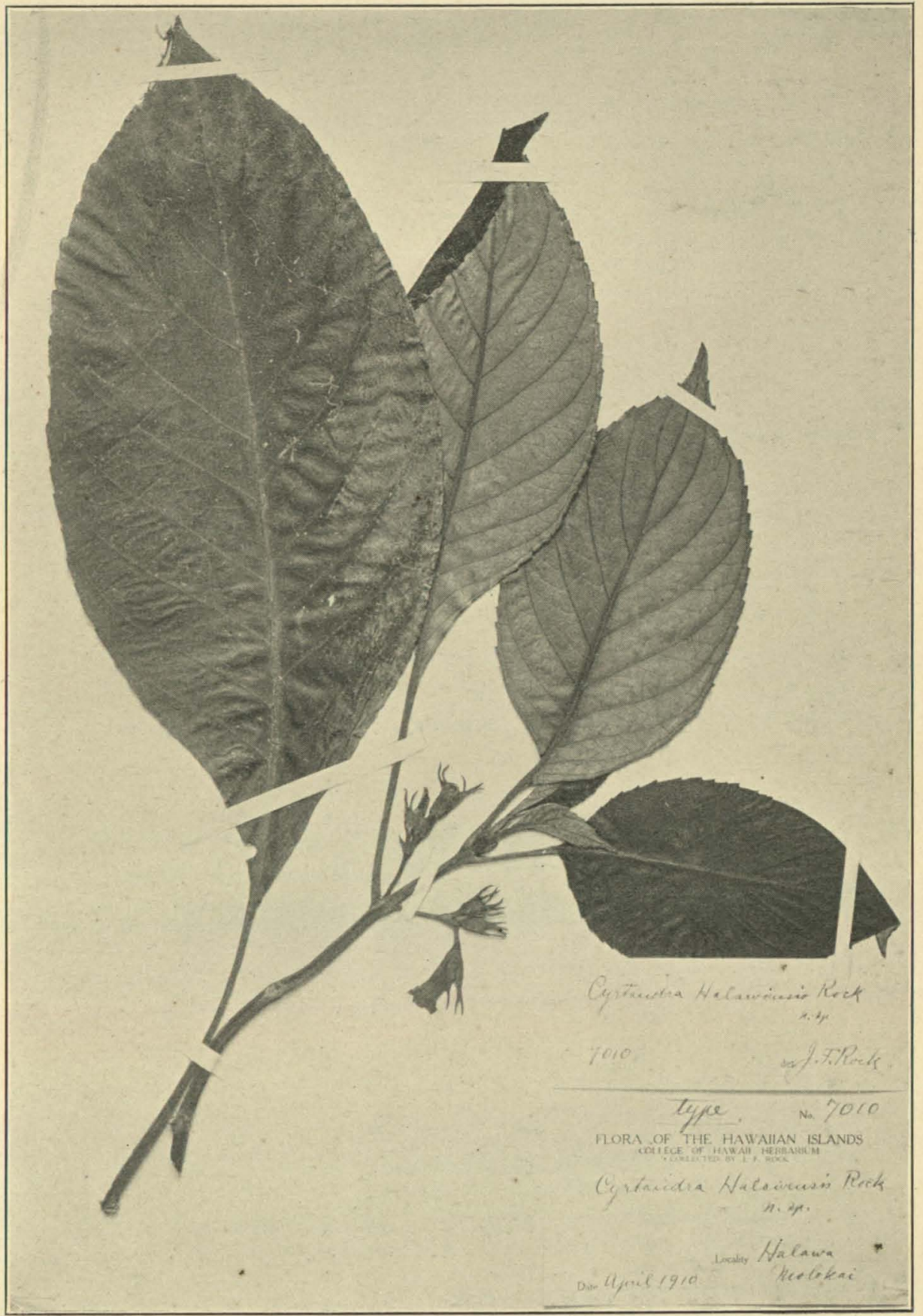

Rock: Type of Cyrtandra halawensis Rock. 


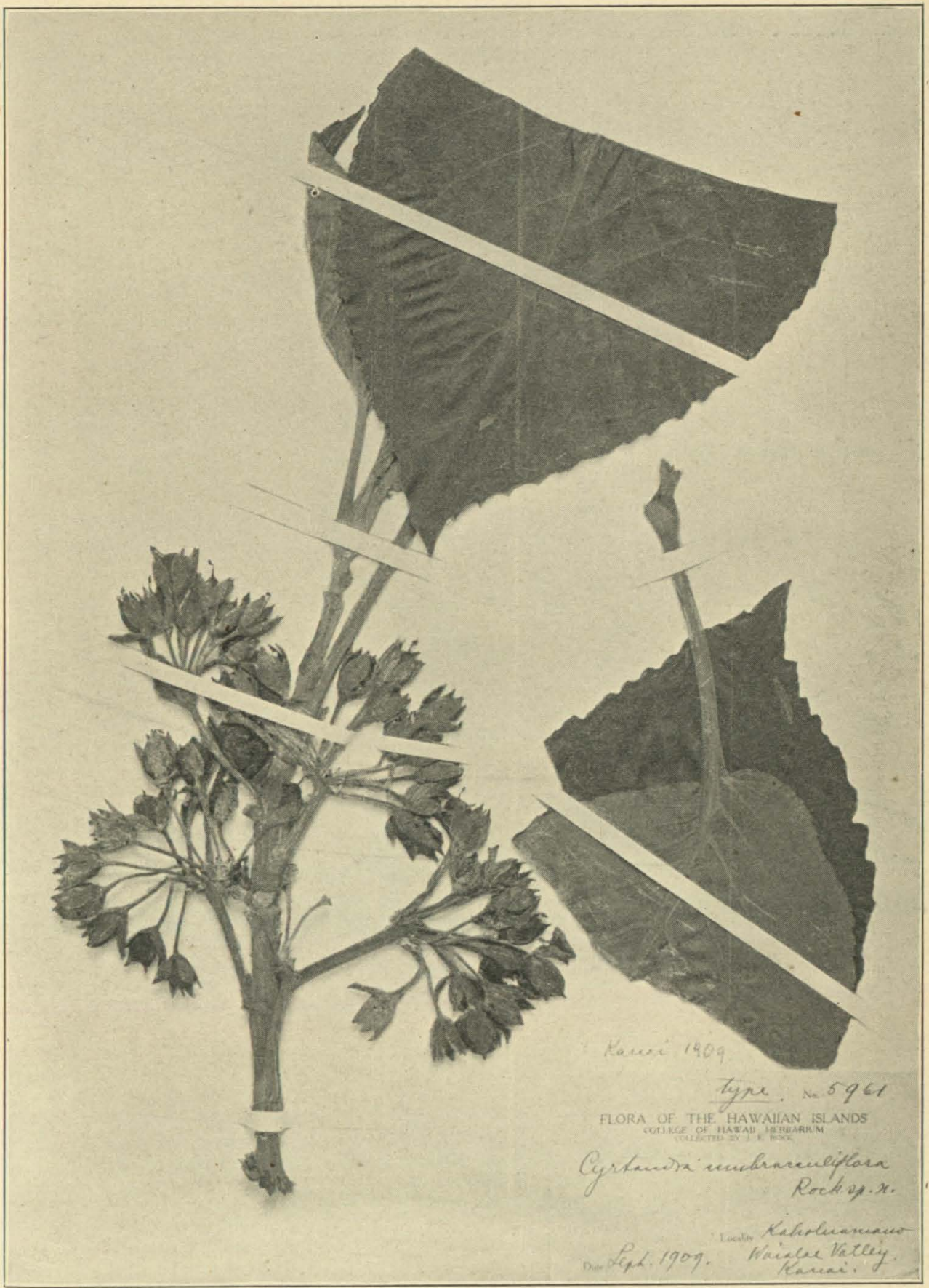

Rock: Type of Cyrtandra umbracculiflora Rock. 


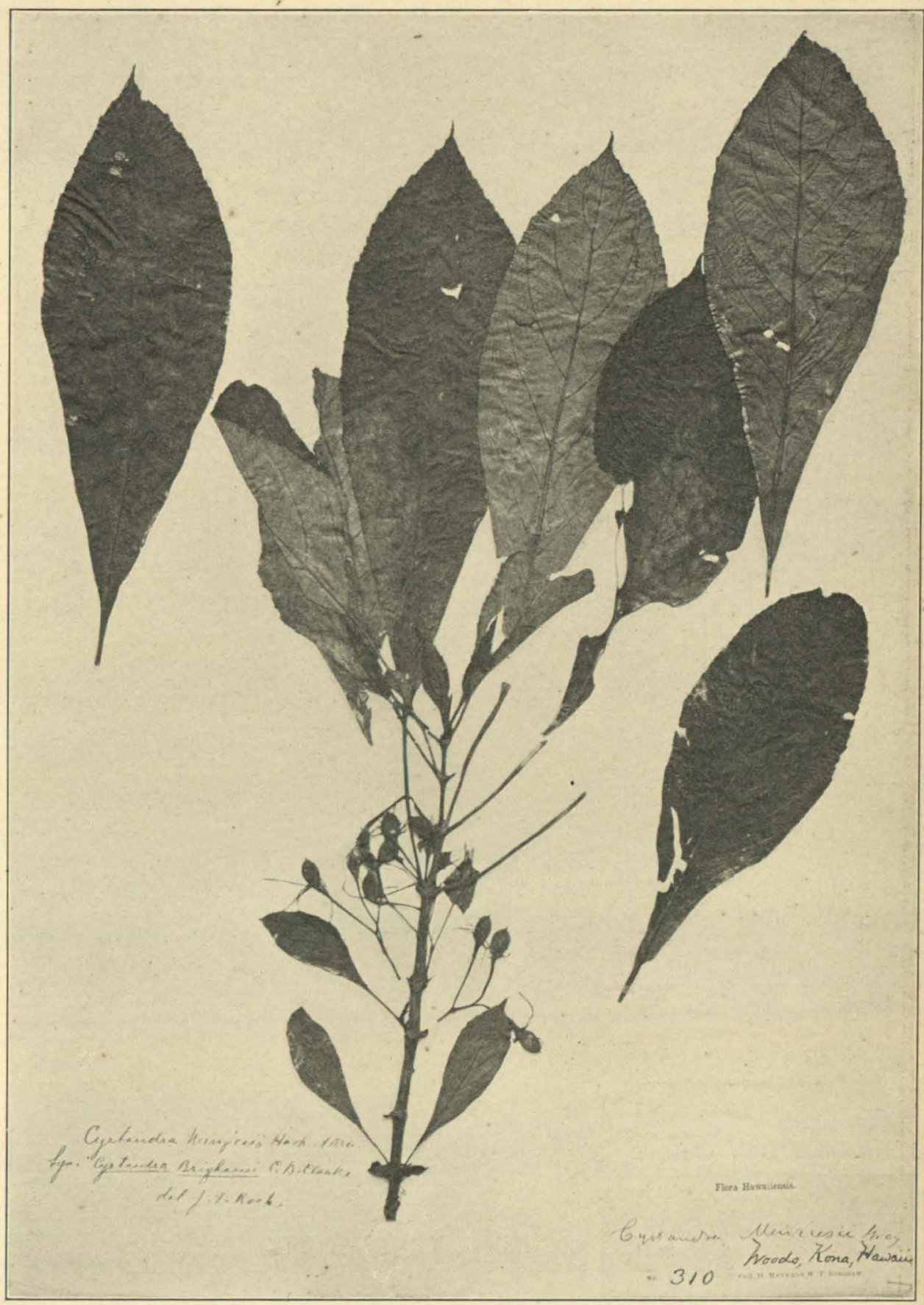

Rock: Cyrtandra Menziesil Hook. \& Arn. 


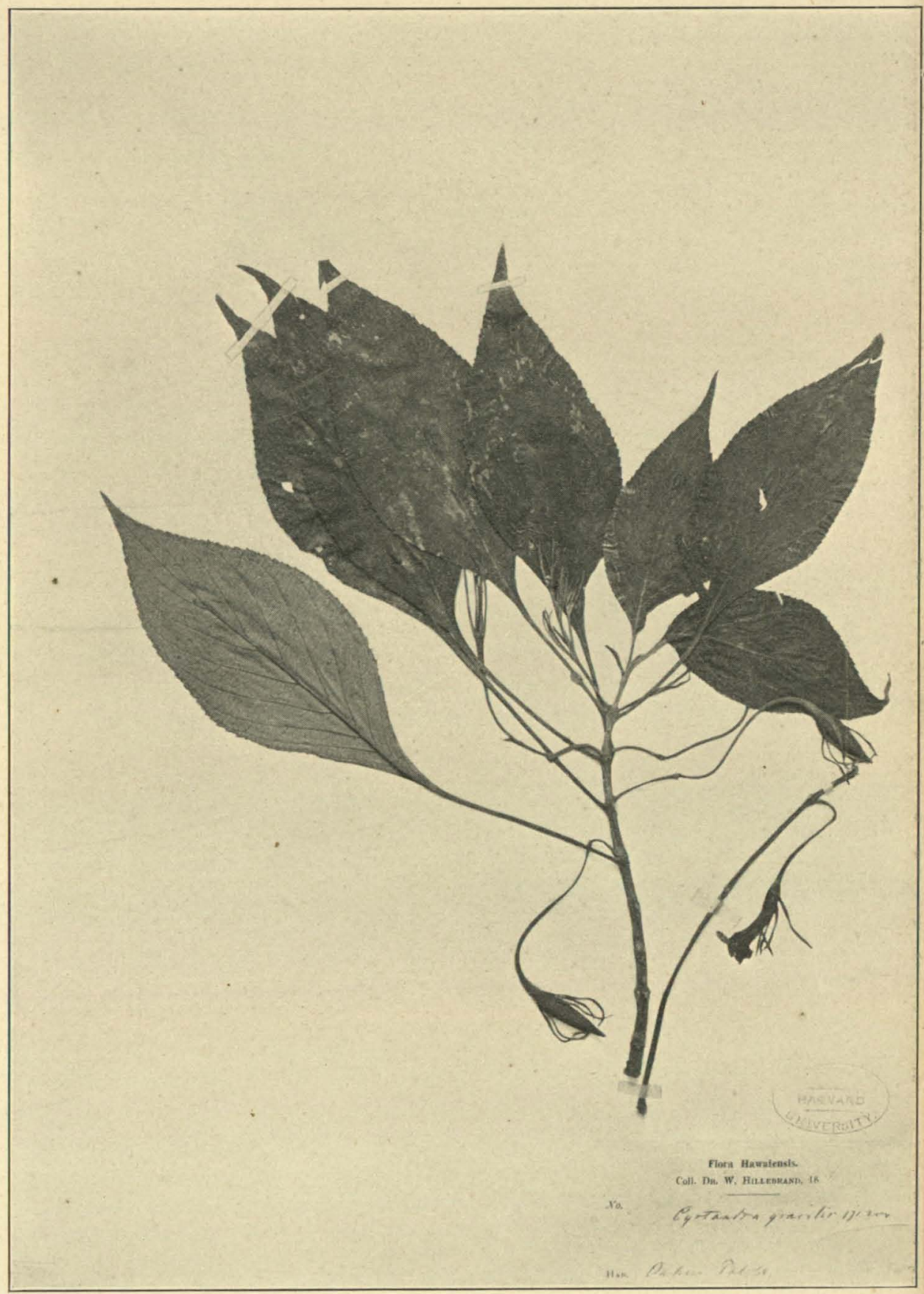

Rock: Cyrtandra gracilis Hillebr. 


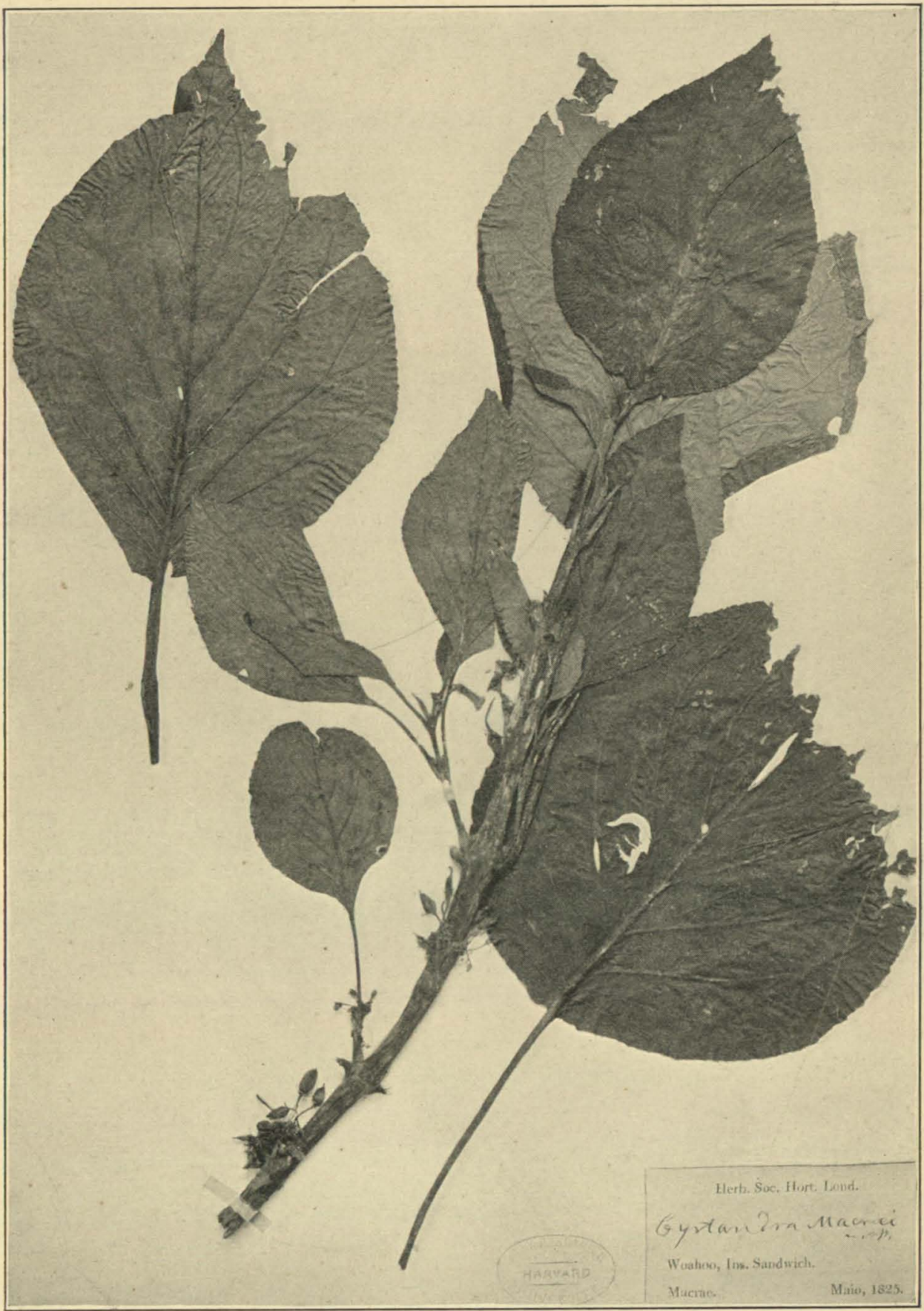

Rock: Type of Cyrtandra Macraei A. Gray. 